\title{
The secret enemy during a flight: Economy class syndrome
}

\author{
Cengiz Şabanoğlu (1)
}

Department of Cardiology, Kırıkkale Yüksek İhtisas Hospital; Kırıkale-Turkey

\section{ABSTRACT}

Deep venous thrombosis (DVT) and pulmonary thromboembolism (PTE) are the major causes of morbidity and mortality in immobile patients. There is observational evidence that intercontinental air travel is associated with a high incidence of DVT and PTE during or within 48 hours of long-distance flights. This situation is known as the economy class syndrome and can affect both the cabin crew and passengers. The term "economy class syndrome" refers to the occurrence of thrombotic events that mainly occur in passengers in the economy class of the aircraft during long-haul flights. This syndrome results from several factors related to the aircraft cabin and the passenger, acting together to predispose to excessive blood coagulation, which can result in venous thromboembolism. In this review, we have shared the relationship between air travel and the formation of DVT and PTE.

Keywords: immobile patients, long-distance flights, observational evidence, pulmonary thromboembolism venous thrombosis

\section{Introduction}

Air transportation is becoming popular by day, mainly because of today's modernized airplanes that are fast, safe, and comfortable. However, this brings along with it health problems. Approximately, 1 billion people travel around the world by air every year (1), and at least $5 \%$ of them are patients with chronic health problems (2).

Venous thromboembolism (VTE) is a clinical condition that involves two related issues, venous thrombosis and pulmonary embolism (PE) (3). It affects approximately 2-3 individuals per 1000 per year. VTE is the third cause of death by vascular diseases, only surpassed by myocardial infarction and ischemic stroke. In addition, it is the most common cause of preventable death in hospitalized patients $(4,5)$. It is difficult to identify the true incidence owing to asymptomatic cases, and postmortem studies indicate higher incidence of deep vein thrombosis (DVT) than is known. Even though the incidence of symptomatic passenger thrombosis is unknown, it is believed that there are 30,000 cases per year in the UK. The annual incidence is $1 / 1,000$ among the general population, $0.4-3 / 10,000$ (6) among travelers, and $1-2.5 / 10,000$ among airplane passengers (7). The incidence of DVT and pulmonary thromboembolism (PTE) because of age and sex varies. For instance, it may be $10.7 \%$ among male patients around the age of 80 years (8). DVT is more common in women in the reproductive age group, whereas it is more common in men after 45 years of age. In general, it is more common in men than in women (1.2/1) (9). The first cases of VTE associated with air travel were reported in 1954; and since then, other cases have been described (10). The vast majority of victims suffer PE and/or DVT; but patients with subclavian vein thrombosis (11), cerebral vein thrombosis (12), stroke, and arterial thrombosis (13) have also been reported. Homans reported the first venous thrombosis seen owing to flight inactivity in a 54-year-old physician during a 14-hour flight from Venezuela to Boston (14).

In a cohort of healthy subjects, the absolute risk of VTE on flights lasting more than 4 hours was 1 in 6,000 (15). A metaanalysis involving 14 studies reported 4,055 cases of VTE in trips lasting up to 8 hours (16). These studies included both air and overland trips with the follow-up time after the journey ranging from 2 to 8 weeks. The relative risk for VTE was 2.8 and at each increment of 2 hours in travel time, there was an approximate $18 \%$ increase in the risk of VTE. Considering only air travel, this risk increased to $26 \%$, suggesting a cumulative effect of flight time in the genesis of VTE.

MacCallum et al. (17) demonstrated that on flights lasting less than 4 hours, the risk of VTE was approximately two times higher than in patients who did not travel and remained high in the 4 subsequent weeks. In long-haul flights (greater than 12 hours as one or more flights), the risk of VTE was around three

Address for Correspondence: Dr. Cengiz Şabanoğlu, Department of Cardiology, Kırıkkale Yüksek İhtisas Hospital; Kırıkkale-Turkey Phone: +90 5322804856 E-mail: drchingiz23@gmail.com 
times higher. After 12 weeks, no time-flight effect was observed in the occurrence of thrombotic events.

It was found around 60 years ago that air travel expedited the formation of DVT, and the term "economy class syndrome" was defined by Symington and Stack who were inspired by patients in whom PTE developed after air travel in 1977 (18). Economy class syndrome refers to the occurrence of thrombotic events during long-haul flights, mainly in economy class passengers. The clinical condition defined here is observed not only in those travelling in economy class, but also in those travelling by land according to the studies. As the cabin crew is constantly on the move, their DVT risks are very low; however, pilots who sit in the cockpit for long hours are also at high risk of developing DVT. PTE is a condition that defines the migration of thrombus formed in systemic deep veins to the pulmonary vascular bed and has high mortality and morbidity rates (19). The death of a 27 -yearold female passenger because of PE during a flight to London in 2001 raised the importance of the issue (20).

This syndrome results from several factors related to the aircraft cabin (immobilization, hypobaric hypoxia, and low humidity) and to the passenger (such as obesity, thrombophilia, oral contraceptive use, hormone replacement therapy, and cancer) that act together, predisposing an individual to excessive blood coagulation, which can result in VTE $(10,21)$. Several risk factors, both genetic and acquired, are associated with VTE. The most important genetic risk factors are natural anticoagulant deficiencies (22), such as deficiency of antithrombin, protein C, or protein $S(4)$; factor V Leiden, which is resistant to protein $C$ inactivation (5); G20210, a mutation in the prothrombin gene, which leads to an increase in gene expression and prothrombin plasma levels (10); C10034T mutation in the fibrinogen gene, which produces a variant form of fibrinogen (22); and non- 0 blood group $(A, B$, and $A B$ ) individuals who have a higher von Willebrand factor and factor VIII plasma levels than 0 group individuals and thus an increased risk of thrombosis. Acquired risk factors include age, pregnancy, surgery, obesity, cancer, hormonal contraceptives and hormone replacement therapy, antiphospholipid syndrome, infections, immobilization, and smoking $(22,23)$. The aircraft microenvironment provides very specific conditions, such as reduced oxygen tension, immobilization (in general, people are in tight uncomfortable seats), and circadian dysrhythmia owing to the differences in time zones (jet lag). These factors may disturb the passenger's health, causing fatigue, anxiety, and nausea $(24,25)$.

Stasis and hypercoagulability, the two components of Virchow's triad firstly stated in 1856, have a crucial role in the occurrence of thromboembolism on flights (16). In long duration air travel, the fact that the legs remain immobile and still in a certain position for hours slows down blood circulation; and the compression of the venous veins, especially those below the knee (popliteal) by the edge of the seat, prevents the blood flow to the veins (26). Because of the stasis formed here, some of the plasma leaks out of the vein, and the density of the blood in the vein increases. It has been shown that sitting in the same position for an uninterrupted hour significantly decreas- es the blood flow rate and increases the protein ratio, hematocrit, and viscosity of blood circulation in the lower extremity. As a result, the hindered blood flow, condensation of the blood, and injuries in the intravascular wall facilitate thrombus formation (27).

Ninety-four percent of intravascular blood clots are silent; the process continues without showing any symptoms and resolves within months. What is more dangerous than embolism and circulatory disorder caused by thrombus is that the thrombus parts may lead to PE. Dyspnea, tachypnea, or chest pain was reported by more than $90 \%$ of the patients who developed PE (28). Today, the risk factors for PTE are analyzed in two main groups; hereditary (primary) which typically results in hypercoagulation and acquired (secondary) risk factors which may lead to endothelial damage and stasis $(19,29)$.

A number of factors associated both with the aircraft or passengers have been singled out as responsible for triggering VTE (30). The factors associated with the aircraft include:

Hypobaric hypoxia: The hypoxia caused by reduced air pressure in the aircraft cabin contributes to VTE. At sea level, normal atmospheric pressure is $760 \mathrm{~mm} \mathrm{Hg}$, which corresponds to a partial oxygen pressure of $159 \mathrm{~mm} \mathrm{Hg}$. Under these conditions, oxygen saturation in healthy individuals is $95 \%$. In the cockpit of an aircraft at flight altitude, the pressure is usually 570 $\mathrm{mm} \mathrm{Hg}$, and the partial oxygen pressure is $125 \mathrm{~mm} \mathrm{Hg}$, resulting in oxygen saturation of $90 \%-93 \%$. However, in older individuals or those with lung and/or heart diseases, reduction of up to $80 \%$ of oxygen saturation can occur. The relative hypoxia in the aircraft leads to a decrease in fibrinolytic activity and the release of venous relaxation factors, which help increase the hemostasis (25). Complaints may be heard within the first 24 hours following landing of the plane; however, in one study, symptoms were observed in 4 patients during travel, in 8 patients on the first day after the flight, and in 27 patients within the first 15 days after travel. The time of emergence of DVT findings was reported on the fourth day following travel on average (31).

Low humidity: The relative humidity inside an aircraft is approximately $10 \%$, whereas at sea level it is $30 \%-40 \%$. Low humidity is associated with increase in plasmatic and urinary osmolarity, which results in hemoconcentration that favors VTE (25). Simons and Krol (32) showed that plasma and urine osmolarity increased after 8 hours of aircraft travel in healthy people at an altitude of 8,000 feet.

The main passenger-related factors are:

Immobilization: Lack of movement in the sitting position during the flight results in hemostasis of the lower limbs, predisposing an individual to VTE (25). An evaluation of coagulation biomarkers showed that there is an increased generation of thrombin during flights lasting more than 8 hours; however, this does not occur in other situations where the subject is immobilized in the sitting position. It suggests that there is an additional mechanism resulting in hypercoagulability during flights (30). 
Body mass index (BMI) and height: In obese individuals $\left(B M I>30 \mathrm{~kg} / \mathrm{m}^{2}\right)$, there is a reduction in blood flow in the lower limbs, favoring hemostasis increasing the risk of VTE during air travel (25).

Thrombophilia: The presence of genetic thrombophilia is an independent risk factor for VTE. Martinelli et al. (33) reported that the risk of VTE is 6.6 times higher in patients with thrombophilia than in those without these mutations. In patients with thrombophilia, the risk of VTE was 16.8 times higher than in those without thrombophilia and air travel, which suggests a synergistic interaction resulting in an increase in thrombotic risk.

Oral contraceptives and hormone replacement therapy. The use of oral contraceptives increases the risk of VTE by approximately four times in the general population. Similarly, hormone replacement therapy is a risk factor for VTE (4).

Cancer: It is well established that patients with cancer have an increased risk of developing VTE throughout the history of the disease, mainly in the first 3 months after the initial diagnosis (34). Kuipers et al. (35) estimated that the presence of a malignant disease was associated to an 18-fold increase in thromboembolic risk during flights.

Other factors: Although it is admitted that factors such as diabetes and smoking are associated with a hypercoagulable state (36), there is a lack of studies about the association of these conditions and the incidence of VTE during flights.

\section{Air travel and venous thrombosis in pregnancy}

Pregnant women in four-hour flights have a thromboembolic risk 5 to 10 times higher than non-pregnant women. This risk rises exponentially on long-haul trips (37). In addition to genetic thrombophilia, parturient women with acquired thrombophilia such as antiphospholipid syndrome have an increased risk for VTE. These findings raise the debate regarding the relevance of the adoption of pharmacological prophylaxis in pregnant women when flying $(38,39)$. Many commercial airlines allow pregnant women to travel only up to the $36^{\text {th }}$ week of pregnancy because of these risks. Other companies make restrictions for international flights in early pregnancy and require evidentiary documentation of gestational age or state that cases should be evaluated individually.

Preventive measures are extremely important. Passengers should be informed of potential risks and encouraged to exercise regularly, with short walks in the aisles, and to avoid dehydration. It is controversial as to whether drinking alcoholic beverages increases the risk of thromboembolic events, but it may contribute to dehydration; and there is still the possibility of fetus damage during pregnancy. Thus, the intake of alcoholic beverages must be discouraged (40). The choice of a suitable outfit for the trip is also important and must prioritize comfort,

\begin{tabular}{|ll|}
\hline \multicolumn{2}{|l|}{$\begin{array}{l}\text { Table 1. Risk categories for the occurrence of thromboembolic } \\
\text { events }\end{array}$} \\
\hline Risk & Risk category \\
\hline Low & $\begin{array}{l}\text { Age over } 40 \text { years, obesity, inflammatory disease, } \\
\text { recent minor surgery (within } 3 \text { days). }\end{array}$ \\
& $\begin{array}{l}\text { Varicose veins, decompensated heart failure, recent } \\
\text { acute myocardial infarction (within } 6 \text { weeks), hormone } \\
\text { therapy (including contraceptives), pregnancy or the } \\
\text { postpartum period, lower limb hemiparesis, lower limb } \\
\text { trauma (within 6 weeks). }\end{array}$ \\
& $\begin{array}{l}\text { Previous venous thromboembolism, known } \\
\text { thrombophilia, recent major surgery (within } 6 \\
\text { weeks), prior stroke, cancer, family history of venous } \\
\text { thromboembolism. }\end{array}$ \\
&
\end{tabular}

avoiding tight garments with elastic. Adequate hydration should be encouraged (38).

Individual risk stratification is essential to define the most appropriate measures. The Aerospace Medical Association has published guidelines on the use of prophylaxis in individuals who travel by air. The risk groups defined in these guidelines are shown in Table 1 (41). Pregnancy and puerperium are defined as moderate risk. For individuals with moderate risk, the guidelines suggest the use of acetylsalicylic acid or compression stockings (42). However, the evidence about acetylsalicylic acid use is controversial as it crosses the placenta and therefore cannot be recommended prophylactically in pregnant women according to the guidelines of the American College of Chest Physicians (43). Low molecular weight heparin may be advised in those who remain immobile for reasons such as thromboembolic diseases, cancer, and recent surgery. Individuals at risk for PE may be administered oral anticoagulant medications or acetylsalicylic acid (44).

Elastic compression stockings exert graduated pressure on the lower limbs with greater pressure at the ankle. When combined with muscle activity, they direct blood flow from the superficial venous system to the deep system, reducing venous stasis and potentially preventing the occurrence of venous thrombosis. A Cochrane systematic review included 9 randomized trials (2,821 individuals) comparing flyers who used compression stockings with those who did not 7 studies in low- or mediumrisk individuals). The study noted a significant reduction in the risk of asymptomatic travel-related DVT with the use of compression stockings (odds ratio: $0.10 ; 95 \%$ confidence interval: 0.05-0.25) (13).

For high-risk individuals, frequent walking, calf muscle exercises, and compression stockings should be encouraged (38, 41). Despite the fact that thrombophilia constitutes a major risk factor for VTE, routine screening is not recommended in pregnant women as there are multiple risk factors (45).

\section{Conclusion}

Air travel longer than 8 hours have been found to increase the risk of developing DVT and PTE. Long-term, uninterrupted 
car and train journeys have also been reported to pose risks for PTE. Considering that PTE has a high mortality and morbidity rate and may occur even weeks after the travel, the incidence of travel-related PTE is thought to be underestimated in the literature.

Conflict of interest: None declared.

\section{References}

1. Ekici B, Erkan AF. Economy Class Syndrome: DVT/PTE on Long Term Flights, Risk, Precautions That Can Be Taken. Turkish Seminars in Cardiology 2015; 3: 180-5.

2. British Thoracic Society Standards of Care Committee. Managing passengers with respiratory disease planning air travel: British Thoracic Society recommendations. Thorax 2002; 57: 289-304. [Crossref]

3. Tapson VF. Acute pulmonary embolism. N Engl J Med 2008; 358: 1037-52. [Crossref]

4. Reitsma PH, Versteeg HH, Middeldorp S. Mechanistic view of risk factors for venous thromboembolism. Arterioscler Thromb Vasc Biol 2012; 32: 563-8. [Crossref]

5. Lapner ST, Kearon C. Diagnosis and management of pulmonary embolism. BMJ 2013; 346: f757. [Crossref]

6. Kesteven PL. Traveller's thrombosis. Thorax 2000; 55 Suppl 1 (Suppl 1): S32-6. [Crossref]

7. Dimberg L. Deep venous thrombosis in a sample of frequent international travellers. Stress, the Business Traveller and Corporate Health: An International Travel Health Symposium 2000. The World Bank, Washington DC.

8. Meisner MH, Strandness E. Pathophysiology and natural history of acute deep venous thrombosis. In: Rutherford RB, editor. Rutherford Vascular Surgery, 5th edition, 2000 Vol II. Philadelphia, 2000, W.B Saunders Co.; Chap 133; p.1920.

9. Heit AJ. Cancer and venous thromboembolism: scope of the problem. Cancer Control 2005; 12 Suppl 1: 5-10. [Crossref]

10. Mendis S, Yach D, Alwan A. Air travel and venous thromboembolism. Bull World Health Organ 2002; 80: 403-6.

11. Teruya Theodore, Arfvidsson Berndt, Eklof Bo. Could prolonged air travel be casually associated with subclavian vein thrombosis. $J$ Travel Med 2002; 9: 17-9. [Crossref]

12. Pfausler B, Vollert H, Bösch S, Schmutzhard E. Cerebral Venous Thrombosis - A New Diagnosis in Travel Medicine? J Travel Med 1996; 3: 165-7. [Crossref]

13. Kakkos SK, Geroulakos G. Economy class stroke syndrome: case report and review of the literature. Eur J Vasc Endovasc Surg 2004; 27: 239-43. [Crossref]

14. Homans J. Thrombosis of the deep leg veins due to prolonged sitting. N Engl J Med 1954; 250: 148-9. [Crossref]

15. World Health Organization (WHO). Wright Project. 2013 [cited 2013 May 11] [Internet]. Available from: URL; http://www.who.int/cardiovascular diseases/wright project/phase1 report/WRIGHT\%20 REPORT.pdf.

16. Chandra D, Parisini E, Mozaffarian D. Meta-analysis: travel and risk for venous thromboembolism. Ann Intern Med 2009; 151: 180-90. [Crossref]

17. MacCallum PK, Ashby D, Hennessy EM, Letley L, Martin J, Mt-Isa $\mathrm{S}$, et al. Cumulative flying time and risk of venous thromboembolism. Br J Haematol 2011; 155: 613-9. [Crossref]
18. Symington IS, Stack BH. Pulmonary thromboembolism after travel. Br J Chest 1977; 17: 138-40. [Crossref]

19. Arseven O. Akut pulmoner embolizm. Ekim N, Türktaş H (editörler). Göğüs Hastalıkları Acilleri. Ankara: Bilimsel Tıp Yayınevi, 2000: 24766. [Turkish]

20. Geroulakos $\mathrm{G}$. The risk of venous thromboembolism from air travel. BMJ 2001; 322: 188. [Crossref]

21. Dusse LMS, Silva MVF, Freitas LG, Marcolino MS, Carvalho MDG. Economy class syndrome: what is it and who are the individuals at risk? Rev Bras Hematol Hemoter 2017; 39: 349-53. [Crossref]

22. Mackman N. New insights into the mechanisms of venous thrombosis. J Clin Invest 2012; 122: 2331-6. [Crossref]

23. Alpoim PN, de Barros Pinheiro M, Junqueira DR, Freitas LG, das Gracas Carvalho $M$, Fernandes $A P$, et al. Preeclampsia and $A B O$ blood groups: a systematic review and meta-analysis. Mol Biol Rep 2013; 40: 2253-61. [Crossref]

24. Artal R, Fortunato V, Welton A, Constantino N, Khodiguian N, Villalobos $L$, et al. A comparison of cardiopulmonary adaptations to exercise in pregnancy at sea level and altitude. Am J Obstet Gynecol 1995; 172 (4 Pt 1): 1170-8. [Crossref]

25. Sandor T. Travel thrombosis: pathomechanisms and clinical aspects. Pathophysiology 2008; 15: 243-52. [Crossref]

26. Cruickshank JM, Gorlin R, Jennett B. Air travel and thrombotic episodes: the economy class syndrome. Lancet 1988; 2: 497-8. [Crossref]

27. Moyses C, Cederhom-Williams SA, Michel CC. Haemoconcentration and accumulation of white cell in the feet during venous stasis. Int J Microcicr Clin Exp 1987; 5: 311-20.

28. Wells PS, Ginsberg JS, Anderson DR, Kearon C, Gent M, Turpie AG, et al. Use of a clinical model for safe management of patients with suspected pulmonary embolism. Ann Intern Med 1998; 129: 9971005. [Crossref]

29. Kolsuz M. Venöz trombüs ve tromboemboli risk faktörleri. Metintaş M (editör). Pulmoner Tromboemboli. Eskişehir: Metin Ofset Matbaacılık, 2001: 21-41. [Turkish]

30. Schreijer AJ, Cannegieter SC, Meijers JC, Middeldorp S, BullerHR, Rosendaal FR. Activation of coagulation system during airtravel: a crossover study. Lancet 2006; 367: 832-8. [Crossref]

31. Mercer A, Brown JD. Venous thromboembolism associated with air travel: a report of 33 patients. Aviat Space Environ Med 1998; 69: 154-7.

32. Simons R, Krol J. Jet leg, pulmonary embolism, and hypoxia. Lancet 1996; 348: 416. [Crossref]

33. Martinelli I, Taioli E, Battaglioli T, Podda GM, Passamonti SM, Pedotti $P$, et al. Risk of venous thromboembolism after air travel: interaction with thrombophilia and oral contraceptives. Arch Intern Med 2003; 163: 2771-4. [Crossref]

34. Khorana AA. Cancer and coagulation. Am J Hematol 2012; 87 Suppl1: S82-7. [Crossref]

35. Kuipers S, Venemans A, Middeldorp S, Büller HR, Cannegieter SC, Rosendaal FR. The risk of venous thrombosis after air travel: contribution of clinical risk factors. Br J Haematol 2014; 165: 412-3. [Crossref]

36. Domingueti CP, Dusse LM, Carvalho Md, de Sousa LP, Gomes KB, Fernandes AP. Diabetes mellitus: The linkage between oxidative stress, inflammation, hypercoagulability and vascular complications. J Diabetes Complications 2016; 30: 738-45. [Crossref]

37. Cannegieter SC, Rosendaal FR. Pregnancy and travel-related thromboembolism. Thromb Res 2013; 131 Suppl 1: S55-8. [Crossref] 
38. Brenner B. Prophylaxis of travel-related thrombosis in women. Thromb Res 2009; 123 Suppl 3: S26-9. [Crossref]

39. Cannegieter SC, Doggen CJ, van Houwelingen HC, Rosendaal FR. Travelrelated venous thrombosis: results from a large population-based case control study (MEGA study). PLoS Med 2006; 3: e307. [Crossref]

40. Brenner B. Interventions to prevent venous thrombosis after air travel, are they necessary? Yes. J Thromb Haemost 2006; 4: 2302-5. [Crossref]

41. Moyle J. Medical guidelines for airline travel. Aviat Space Environ Med 2003; 74: 1009.

42. Aerospace Medical Association Medical Guidelines Task Force. Medical Guidelines for Airline Travel, 2nd ed. Aviat Space Environ Med 2003; 74 (5 Suppl): A1-19.
43. Geerts WH, Bergqvist D, Pineo GF, Heit JA, Samama CM, Lassen MR, et al. Prevention of venous thromboembolism: American College of Chest Physicians Evidence-Based Clinical Practice Guidelines (8th Edition). Chest 2008; 133 (6 Suppl): 381S-453S. [Crossref]

44. Sarıgül A, Tanyeli Ö. Current treatment strategies in deep vein thrombosis. Turkish J Thorac Cardiovasc Surg 2007; 15: 316-21.

45. Bates SM, Greer IA, Middeldorp S, Veenstra DL, Prabulos AM, Vandvik PO. VTE, thrombophilia, antithrombotic therapy, and pregnancy: Antithrombotic Therapy and Prevention of Thrombosis, 9th ed: American College of Chest Physicians Evidence-Based Clinical Practice Guidelines. Chest 2012; 141 (2 Suppl): e691S-736S. [Crossref] 